\section{The Effect of "Whatsapp" Usage on the Attitudes of Students Toward English Self-Efficacy and English Courses in Foreign Language Education Outside the School}

\author{
Bilge Çam Aktaşa, ${ }^{a}{ }^{*}$ Yafes Can ${ }^{b}$
}

$\begin{array}{ll}\text { Received: } & 11 \text { December } 2018 \\ \text { Revised: } \quad 11 \text { January } 2019 \\ \text { Accepted: } \quad 20 \text { January } 2019 \\ \text { ISSN: 1307-9298 } \\ \text { Copyright @ IEJEE } \\ \text { www.iejee.com }\end{array}$

DOI: 10.26822/iejee.2019349249

\begin{abstract}
The aim of this study is to examine if using WhatsApp actively in English outside the school has any effect on the students' attitudes and self-efficacy belief on English course. In this study, a sequential explanatory pattern was used. In order to obtain quantitative data, one group pretest-posttest design was used. The participants consist of 11th grade students studying in an Anatolian High School in the center of Sivas. The implementation of the study lasted eight weeks. In terms of the experiment, WhatsApp meetings were held twice a week for evaluating the achievement of 11 th grade English course. "English Self-Efficacy Scale" and "Attitude toward English Scale" were applied before and after the experiment. In addition, semi-structured questionnaire was used in order to get the opinions of the students about the implementation at the end of the experiment. The results of the study revealed that using WhatsApp outside the course leads to a significant differentiation in the self-efficacy beliefs of the students for both reading and listening. The data obtained from qualitative processes also confirm this. In addition, it shows that the practice has a statistically meaningful effect on students' attitudes toward the course. The data obtained from the qualitative processes have proved that the implementation is influential in the emotions such as happiness, joy, excitement, pride and that the students considerably support the use of this implementation.
\end{abstract}

Keywords: WhatsApp, Language Teaching, Attitude, Self-efficacy Belief

\section{Introduction}

Certainly, ability to speak a foreign language is very important in every aspect of life as well as to be able to follow developments around the world. Hence, the foreign language education occupies a significant place in Turkey as in other countries of the world (Akkaş \& Coker, 2016). However, it is commonly admitted that foreign language education in our country doesn't realize its purposes. After studying a foreign language for 10 years including secondary school, it is observed that majority of the students are still at the beginner level (Demirpolat, 2015). This is also apparent in the English proficiency levels in the English Proficiency Index (conducted by EPI) by many countries (EF EPI, 2018). According to data of 2018, Turkey ranks 31th among 32 countries in Europe while it ranks 73th between Nicaragua and Jordan among 88 countries in the world. As Turkey ranked 32nd among 44 countries in 2012, this shows that the current problem is continuing (EF EPI, 2018). This issue was largely investigated with many studies in our country and it is observed that the problem has many various dimensions. Among the factors affecting language teaching, it has been noted that there are several factors such as students' attitude toward language learning, motivation, concerns, insufficiencies about teaching tools and equipment, the fact that the lessons are strongly based on theoretical knowledge, the fact that the students feel reluctant to learn a language, and finally inadequate use of technology (Aydın \& Zengin, 2008; Baran \& Halıcı, 2006; Çelebi, 2006; Gedikoğlu, 2005; Gökdemir, 2010; Kazazoğlu, 2013; TEPAV, 2014).

In addition to cognitive factors that influence success in language teaching, affective factors such as attitude, motivation, and self-efficacy are significant as well. In this respect, one of the factors that should be analyzed in foreign language teaching is self-efficacy beliefs. Self-efficacy is defined as one's belief in one's ability to succeed in specific situations or accomplish a task (Bandura, 1977). Zimmerman (2000), on the hand, defines the self-efficacy as the judgments of a person to accomplish a certain task, it does involve the physical or psychological characteristics of the person, not personal qualities. Hence, foreign language self-efficacy perception can be explained as the judgments (Yanar, 2008) of individuals about their ability to regulate and perform the essential activities in order to achieve a certain performance in a foreign language. Self-efficacy constitutes the need to perform in events that may affect the lives of individuals. This condition influences one's feelings, thoughts, motivations, and behaviors (Bandura, 1977). Thus, self-efficacy is a multifaceted phenomenon. Therefore, self-efficacy belief may vary according to the situations and events. For example, a student's self-efficacy in language learning may differ from his/her self-efficacy in physical learning. People with strong self-efficacy are stubborn on the incidents and challenges they encounter, they make more effort and have powerful resistance. This certainly affects the academic success of the person as well (Yılmaz, Yiğit, \& Kaşarcl, 2012).

Another affective feature influencing the students' success in language teaching is the attitudes of students. Attitude is defined as the mental state of readiness (Alport, 1954). Gardner (1985) defined the attitude as an evaluative reaction on the basis of the individual's beliefs or opinions. Many studies have been conducted on the impact of attitude on academic success in foreign language education and a strong relationship has been ascertained between attitude and achievement (Bartram, 2010; Kazazoğlu, 2013; Levin, Naama, \& Zipora, 1991). In addition, it was noted that the attitudes of students have an essential role in the readiness level of the students (Ocak \& Karakuş, 2014). Hence, it can be stated that self-efficacy and attitude are significant in teaching English to students and therefore, self-efficacy and attitude should be

\footnotetext{
a, ${ }^{*}$ Corresponding Author: Bilge Çam Aktaş, Anadolu University, Faculty of Education, Department of Curriculum and Instruction, Eskişehir, Turkey. Phone: +90 2223350580 / 2779.E-mail: bilgec@anadolu.edu.tr 
taken into consideration in the preparation of educational activities and education programs.

The significance of attitudes and self-efficacy experienced in face-to-face educational environments is also valid for distance education applications. Because networks have become stronger in today's technology. Hence, the technology is now used extensively in education and training environments. One of the most critical approaches explaining distance learning on networks that are used for educational purposes is the "Connectivism approach". As the pioneer of this approach, Siemens (2006) asserts that when students use digital tools for communication, an environment has been built to learn, to establish dialogues for learning and to internalize this learning as well. According to Siemens, a connection created in this way allows students to develop the ability to create new information in time (Siemens, 2006). Connectivism theory comprehends learning as a process that can be actualized and developed through the interaction of students with each other in digital environments rather than as an individual activity. Siemens also affirmed that the capability to communicate with others and the capacity to establish networks are essential in ensuring the continuity of information flow (Siemens \& Tittenberger, 2018). Siemens (2006; quoted Gökmen, Duman, \& Horzum, 2016) declares that the learning capacity of individuals is more prominent than the known capacity in the connectivism approach that is based on the capability of the individuals to observe the connection between the fields, ideas and concepts. And he also mentions that communities, e-mails, web searches, blog reading, and chats can be used to implement the principles of the connectivism approach.

Information and communication technologies (ICT) are required in order to implement the connectivism approach in education. The unimaginable speed of information and communication technologies considerably affects every aspect of our lives. In accordance with this change and progress, the use of ICT in our learning life has become undeniable and has been used in many parts of the world, particularly in the United States since the beginning of the 1980s (Bardakcı \& Keser, 2017). Furthermore, the use of ICT in the USA reached $100 \%$ in the 1990 (Cuban, 1994). In our country, within the scope of FATIH project, the technological base in schools has been strengthened and it is intended to increase the quality in education. Moreover, the use of ICT has also become popular in foreign language education in recent years. As the mobile technologies developed unprecedently and various social networking platforms have emerged, people of all ages became dependent on technology. If we examine the statistics published by "We are social" (Kemp, 2018) website we find out that $67 \%$ of Turkey's population is the users of the internet, while $51 \%$ are active members of social media and $54 \%$ use actively social media on mobile devices. It was noted that $98 \%$ of people having a cell phone use a smart phone in Turkey. In the light of statistical data provided by the same website, the people in Turkey are active on social media for an average of 2 hours and 48 minutes per day. Again, when the statistical data are examined, it is observed that "WhatsApp" is the most utilized social media communication tool in the world as of June 2018 and roughly 1.5 billion people use it. In light of this data, we can assume that technology is an essential part of our lives and we are using social media almost every day. Since social media becomes an essential part of our lives, it is inevitable to use it in educational environments. Hence, many studies have been conducted on the use of technology inside and outside the school. As in other fields of education, the use of technology and social media is observed in language teaching as well.
The use of WhatsApp as a communication tool is very popular in Turkey. Therefore, the use of such a generally used platform in educational environments and language teaching is inevitable. The researches conducted revealed that the use of WhatsApp in foreign language education has positive effects on the writing (Alsaleem, 2013; Fattah, 2015), reading (Plana, Gimeno, Appel, \& Hopkins, 2013), speaking (Manan, 2017) skills and on enriching vocabulary (Alsaleem, 2013; Jafari \& Chalak, 2016) (Fattah, 2015) . In addition, it was discovered out that this is influential on the active participation of the students; the students were able to express themselves more comfortably; they had the change to correct their own writing; they experience a better learning experience and it contributed to the positive development of the interaction between student-student and student-teacher outside the school (Fattah, 2015). Also in the literature, it was noted that using WhatsApp encouraged students to read and it helped the students to believe in themselves (Plana, Gimeno, Appel, \& Hopkins, 2013; Alshammari, Parkes, \& Adlington, 2017). In the study conducted by Şahan, Çoban and Razı (2016) about teaching English idioms through WhatsApp, they have mentioned that the use of WhatsApp was influential in foreign language teaching and there were some positive changes in attitudes and motivations of the students. Furthermore, they have mentioned that the learning became entertaining this way and it is possible to use this method for pronunciation, vocabulary, and writing activities (Şahan, Çoban, \& Razı, 2016). Consequently, it has been observed that the use of "WhatsApp" as the social media in language teaching generated positive results. When the literature is reviewed, there is no study that explored the use of social media in secondary education. Furthermore, if we review the studies conducted about the use of WhatsApp in foreign language teaching, we find out that it is influential on vocabulary (Jafari \& Chalak, 2016), idioms (Şahan, Çoban, \& Razı, 2016) learning, writing (Fattah, 2015) and reading (Plana, Gimeno, Appel, \& Hopkins, 2013) skills. On the other hand, in this study, the effects of WhatsApp usage on the affective characteristics of students in English learning were investigated.

Acknowledging the studies conducted before, it is comprehended that almost 2/3 of Turkey's population uses social media (Kemp, 2018). Hence, it is inevitable to use a technology in education since it has been so involved in society. When we examine the researches conducted on social media and education, we find out that there are many studies outside Turkey although there are very few studies conducted in Turkey (Gökmen, Duman, \& Horzum, 2016; Şahan, Çoban, \& Razı, 2016). Consequently, conducting a study on this topic will considerably contribute to the literature.

Specialists in the field of foreign language education apprehend the problems experienced in Turkey. According to the literature, the sources of the difficulties experienced are based on the following reasons; the fact that the education isn't based on practice, the motivation levels of the students and the attitudes of the students toward the course (Aydın \& Zengin, 2008; Baran \& Halıcl, 2006; TEPAV, 2014). Thus, the effect of "WhatsApp" as social media on attitudes of the students toward the English course and self-efficacy beliefs of the students will be examined in this study. In this context, this study is considered to contribute to the related literature.

Aim

The aim of this study is to examine the effect of "WhatsApp" on self-efficacy beliefs and attitudes of students in learning English. In this context, the answers to following questions will be sought: 
1. What is the effect of using WhatsApp correspondence in English outside of the school on self-efficacy beliefs of students in English?

2. What is the effect of using WhatsApp correspondence in English outside of school on the attitudes of the students toward learning English?

3. What are the opinions of students on the use of WhatsApp correspondence in English outside of school?

\section{Method}

\section{Research Model}

The aim of this study is to examine the effect of "WhatsApp" on the self-efficacy beliefs and attitudes of students toward English. Thus, an exploratory sequential pattern was used among mixed research methods. In this design, quantitative data are collected, analyzed and then qualitative data are collected. Hence, the quantitative data has been prioritized. Qualitative data is obtained to develop quantitative data. The analysis of data is interconnected and the data are combined in the interpretation and discussion sections (Creswell \& Clark, 2011). In order to obtain quantitative data, one group pretest-posttest design was used. In this pattern, the dependent variable is applied to a randomly selected group. Measurements are performed before and after the experiment (Karasar, 2014). Furthermore, a semi-structured questionnaire was applied to receive the opinions of students about WhatsApp. In this structure, the independent variable is the use of "WhatsApp" while the dependent variables are self-efficacy in English and attitude toward English course. In order to measure self-efficacy beliefs and attitudes of students, quantitative data collection processes were applied before and after the experiment. Moreover, qualitative data collection processes were used to support quantitative data. Semi-structured survey questions were used to collect qualitative data. The process of the study is presented in Table 1.

Table 1. One group pretest-posttest design

\begin{tabular}{|c|c|c|c|}
\hline Group & Pretest & Process & Posttest \\
\hline \multirow[t]{2}{*}{ G } & $\mathrm{O}_{1}$ & $x$ & $\mathrm{O}_{2}$ \\
\hline & $\begin{array}{l}\text {-English Self- } \\
\text { Efficacy Scale } \\
\text {-Attitude toward } \\
\text { English Scale } \\
\text { (Dependent } \\
\text { Variable) }\end{array}$ & $\begin{array}{l}\text { Discussing in } \\
\text { English with } \\
\text { "WhatsApp" } \\
\text { ap-plication that } \\
\text { lasted } 8 \text { weeks }\end{array}$ & $\begin{array}{l}\text {-English Self- } \\
\text { Efficacy Scale } \\
\text {-Attitude towarc } \\
\text { English Scale } \\
\text { (Dependent } \\
\text { Variable) }\end{array}$ \\
\hline G & & & $\begin{array}{c}\text { Conducting } \\
\text { semi-structured } \\
\text { survey }\end{array}$ \\
\hline
\end{tabular}

\section{Study Group}

The study was carried out with 19 students attending the 11 th grade in an Anatolian High School in the city center of Sivas during the academic year of 2018-2019 and a student studying at another Anatolian high school attending the course program. Demographic data of the study group is presented in Table 2 .

20 students in total participated in the study. While 15 of the students that participated in the study are 16 years old, the remaining 5 students are 15 years old. In terms of gender, it is observed that 8 people in the study groups consisted of males while there are 12 females.

In the study, the time spent by the students on the internet, the aim of their using the internet, the time they spent on social networks and social networks they used the most were checked as well. The following information is obtained accordingly.

Table 2. Demographic Information of the Study Group

\begin{tabular}{ccc}
\hline Study Group & & \\
\hline & & $f$ \\
\hline \multirow{2}{*}{ Gender } & Male & 8 \\
\cline { 2 - 3 } & Female & 12 \\
\hline \multirow{2}{*}{ Age } & 15 & 5 \\
\cline { 2 - 3 } & 16 & 15 \\
\hline
\end{tabular}

Table 3. Social networks used by students

\begin{tabular}{cc}
\hline Social Networks & $f$ \\
\hline Instagram & 11 \\
\hline WhatsApp & 7 \\
\hline Ekşi sözlük & 1 \\
\hline Twitch & 1 \\
\hline Total & 20 \\
\hline
\end{tabular}

Table 4. Time spent by students on the Internet and social networks

\begin{tabular}{|c|c|c|c|c|}
\hline & $\begin{array}{c}\text { Time spent with the } \\
\text { Internet, phone and } \\
\text { computer }\end{array}$ & $f$ & $\begin{array}{l}\text { Time spent on } \\
\text { Social Networks }\end{array}$ & $f$ \\
\hline & 2 hours & 1 & 1 hours & 1 \\
\hline & 3 hours & 10 & 2 hours & 9 \\
\hline & 4 hours & 1 & 3 hours & 5 \\
\hline & 5 hours & 2 & 4 hours & 2 \\
\hline & 6 hours & 2 & 5 hours & 1 \\
\hline & 7 hours & 1 & 6 hours & 1 \\
\hline & 8 hours & 2 & 10 hours & 1 \\
\hline & 11 hours & 1 & & \\
\hline $\begin{array}{c}\text { Average } \\
\text { Time Spent }\end{array}$ & 4.6 hours & & 3.15 hours & \\
\hline
\end{tabular}

As it can be apprehended from the tables, the most common social network that students use "Instagram", which followed by "WhatsApp". It is remarked that the students spend an average of 4.6 hours per day with their phone or computer. When the time spent by students on social networks is considered, it is approximately 3 hours and 15 minutes per day. If we examine the purpose of using the internet, we comprehend that 7 of the students use the internet for correspondence, 7 of the students use the internet for watching videos or movies, 2 of them play games, 2 of them read books and 2 of them use the internet for studying and conducting research.

\section{Experiment}

The online learning process lasted 8 weeks. This process includes 2 themes from the 10th grade English curriculum. One week of 8 weeks was used for online socialization and for checking the suitability of the technical infrastructure. For 7 weeks, the discussion activities were carried out. In this study, Salmon's (2002) five-stage online learning and teaching framework was used. Figure 1 exhibits this model and the process used in the study.

According to this model, there are five stages in the formation of the online learning environment. These stages are as follows: access and motivation, online socialization, information exchange, knowledge structure, and development. This model essentially focuses on how students will 
benefit from online learning environments and how the teacher will follow this process. In the light of this model, "WhatsApp" application, which is a written and oral correspondence platform, has been selected by considering the facility of access. Then, the researcher informed the students during the course to ensure that the students have access to this application and can use the application efficiently. Then a group was created on WhatsApp and the students were asked to participate in this group. The students were generally informed about how to use the platform because they already know how to use "WhatsApp" effectively before the study. Afterward, a welcoming and introducing activity was conducted on platform to ensure that the students socialize. The researcher organized a total of 14 discussion activities each week (2 activities per week) and shared it in the group. The researcher first explained the case in the discussion and then gave some feedback based on the responses of the students. Although the frequency of these feedbacks varies according to the discussion, more feedback has been provided to the students in the first interviews in order to motivate the students, and in the following interviews, the researcher guided the discussion of the students and only intervened for increasing the quality of the discussion. The communications were shared in the form of questions and discussions. The content of these discussions is based on current subjects and values such as love and respect, which are included in secondary education English curriculum, taking into account the 11th-grade achievements of students. These activities were carried out for 8 weeks, one at the weekend and one during the week. The interviews held on weekdays were usually held after 20:00 pm and the weekend meetings were held at any time during the day. When the activity ended, a summary of discussion has been recorded. According to the records, 12,324 words and 58 voicemail messages were used in 14 discussion activities.

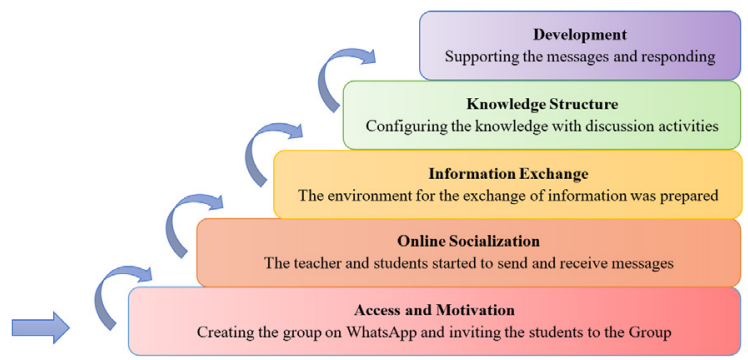

Figure 1. Online learning and teaching framework (Reference: Salmon, G. (2002). E-tivities: The key to active online learning. London: Kogan Page.K)
itios: The key

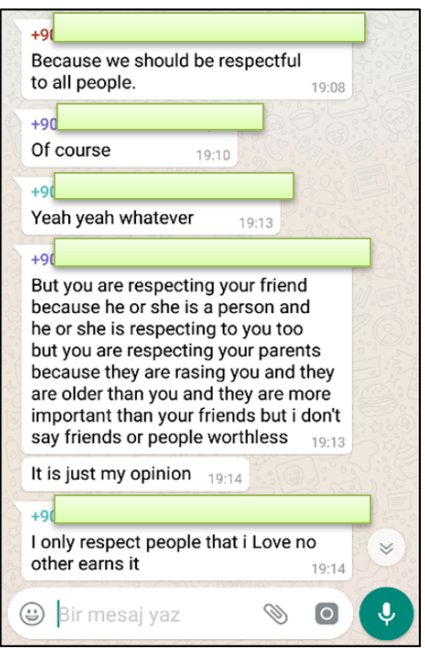

Figure 2. An example of a discussion over WhatsApp

\section{Quality of Online Interaction}

The rubric developed by Roblyer and Wiencke (2003) was used to assess the quality of the interaction in distance education. The ability of students and teacher to conduct online discussions was evaluated according to this rubric. A faculty member, working at the Department of Computer Education and Instructional Technology, conducted the evaluation process. There are three levels of interaction in the rubric to define the quality of the interaction. These are low (1-9 points), medium (10-17 points) and high (1825 points) interaction levels. The level of interaction in this study was found to be 14 points according to the rubric and it was noted that this signifies a moderate interaction (Table 5).

Table 5. The quality of the online learning environment

\begin{tabular}{ccc}
\hline Process & Quality & Points \\
\hline 1. Socialization & $\begin{array}{c}\text { Teachers and students introduced } \\
\text { themselves in the group and gave } \\
\text { short information about themselves. }\end{array}$ & 2 \\
\hline $\begin{array}{c}\text { 2. Design of } \\
\text { Education }\end{array}$ & $\begin{array}{c}\text { Interactions are designed to be } \\
\text { between stu-dent-student and teach- } \\
\text { er-student. }\end{array}$ & 3 \\
\hline $\begin{array}{c}\text { 3. Interaction } \\
\text { of interac-tion } \\
\text { sources }\end{array}$ & $\begin{array}{c}\text { Teachers and students are in two-way } \\
\text { asyn-chronous interaction. }\end{array}$ & 2 \\
\hline $\begin{array}{c}\text { 4. Evidence } \\
\text { revealing the } \\
\text { student's } \\
\text { attachment }\end{array}$ & $\begin{array}{c}\text { Majority of students voluntarily partic- } \\
\text { ipated in discussion activities at a rate } \\
\text { of 70-75\%. }\end{array}$ & 4 \\
\hline $\begin{array}{c}\text { 5. Evidence } \\
\text { revealing } \\
\text { the teacher's } \\
\text { attachment }\end{array}$ & $\begin{array}{c}\text { The teacher usually answers, influ- } \\
\text { ences and directs the opinions of the } \\
\text { students within 2-3 hours. }\end{array}$ & 3 \\
\hline
\end{tabular}

\section{Data Collection Tools}

Three different data collection tools were applied in the study. These are; "English Self-Efficacy Scale" that test the reliability and validity when applied pretest and posttest and that is developed by Yanar and Bümen (2012); "Attitude toward English Scale" developed by Orakçı (2017). Before using the scales, the authors were contacted by e-mail and necessary permissions were obtained. In addition, semi-structured questionnaire questions were used to get opinions of the students about "WhatsApp".

The "English Self-Efficacy Scale" consists of four sub-dimensions and measures the self-efficacy of the students toward reading, writing, speaking and listening. The scale consists of a total of 34 items in five-point Likert type. The reliability of the scale is .97 . The high score obtained from the scale was admitted as an indicator of high self-efficacy belief in English. In this study, Cronbach's Alpha reliability coefficient was calculated andfound to be .94 .

The English attitude scale consists of 16 items answered in five-point Likert-type. While the highest score of the scale is 80 , the lowest score is 16 . The scale has two sub-dimensions: affective and behavioral. The highest score that can be obtained for the affective sub-dimension is 50 , and the lowest possible score is 10 . The highest score for behavioral sub-dimension is 30, and the lowest possible score is 6 . The reliability of the scale is .89. In this study, Cronbach's Alpha reliability coefficient was calculated andfound to be .88. The high score obtained from the scale indicates a positive attitude toward the English course.

In this study, a semi-structured questionnaire was applied to collect qualitative data as well. This method, which is a great method(Yıldırım \& Şimşek, 2013) for revealing people's emotions, thoughts, perspectives, thoughts, and 
experiences, is a process that has been carried out during and after the 8-week study on "WhatsApp", a social media tool and it is used for obtaining in-depth knowledge about the experiences, emotions, and thoughts of the students as well as their self-efficacy beliefs and attitudes toward English. Hence, a literature review on English self-efficacy and attitudes toward English course was conducted. At the end of the literature review, four sub-dimensions of the self-efficacy perception in English were determined. These sub-dimensions are self-efficacy beliefs for reading, writing, listening and speaking. Furthermore, studies on attitudes toward English courses were evaluated and a questionnaire was prepared. First, an evaluation form has been prepared for asking the opinions of the experts and the opinions of 1 Professor Dr., 2 Associate Professors and 2 Academicians were asked about the questionnaire in terms of the content, scope and purpose. In line with the feedback from the experts, the form was corrected accordingly, and it was submitted to the experts again and this process was repeated three times until we have reached a final agreement on the questionnaire. There are 7 questions and 14 inquiry questions in the questionnaire. After preparing the semi-structured questionnaire, the questionnaire was applied to two students, who do not participate in the experiment. In order to prove similarity in terms of age and level with the students in the study, particularly students studying at 11 th grades were selected. In this practice, the clarity of the questions and the time spent on each question were tried to be determined. In the pilot application, students were asked to share their thoughts and suggestions about the questions. Necessary corrections have been made considering the opinions of the students about the clarity of the questions and the time spent on each question. It was noticed that there was no problem in the comprehensibility of any item. Hence, the questionnaire was finalized.

\section{Data Collection}

Data in the study were obtained by quantitative and qualitative data collection processes. For this purpose, first, the Attitude toward English Scale and English Self-Efficacy Scale were used before the application. After eight weeks of implementation, these two scales were applied to the students and the related data were collected. During the implementation of the two scales, students were asked to respond to the questions honestly. In addition, the scales were conducted on different days so that the students respond sincerely.

In the study, the qualitative data were collected from students participating in "WhatsApp" implementation for 8 weeks through a semi-structured questionnaire. The semi-structured questionnaire was implemented on a voluntary basis at the end of the 8-week application. 20 students participated in the study and 19 of these students volunteered to complete the questionnaire. Only 1 student did not want to fill the questionnaire. Hence, data were obtained from a total of 19 students.

\section{Analysis of Data}

The attitudes and self-efficacy of the students toward the English course were measured before and after the application. The "dependent" t-test was performed to examine if there was a significant difference between pretest and posttest. The dependent t-test compares the means (obtained at different times) of two related groups to determine whether there is a statistically significant difference between these means (Can, 2017).

An inductive method was preferred in the analysis of qualitative data. Because the themes and codes were not distinguished before the study. First, qualitative data were written. Then the researcher and the two program development experts have thoroughly read, examined and identified the themes and codes. The interviews were repeated three times until the researchers agreed on the themes and codes, and so, the themes and codes were finalized. In order to increase the reliability, the agreement percentage about the coding of the three researchers was calculated by using the following formula: "Reliability = Consensus/(Consensus+Disagreement) x 100" and the agreement percentage was determined to be .76. Finally, 7 themes and 12 codes have been identified.

\section{Findings}

\section{Findings from Quantitative Data}

Dependent (associated) t-test was used to examine whether the use of WhatsApp has an impact on English self-efficacy perceptions and attitudes toward English course. Before the t-test was performed, the extreme values were examined with Box-Plot and it was determined that one data was found to be extreme for self-efficacy belief in writing. The respective extreme data was removed from the data set and then the normal distribution characteristics of the difference between the pre-test and post-test scores were examined using skewness and kurtosis, Shapiro-Wilk test and Quantile-Quantile plots (Q-Q plots). First, the skewness and kurtosis coefficients of the data were analyzed. The related results are presented in Table 5 .

Table 6. Skewness and kurtosis coefficients of difference points

\begin{tabular}{ccc}
\hline & $\begin{array}{c}\text { Skewness } \\
\text { coefficients }\end{array}$ & $\begin{array}{c}\text { Kurtosis } \\
\text { coefficients }\end{array}$ \\
\hline $\begin{array}{c}\text { The self-efficacy average points for } \\
\text { English reading }\end{array}$ & .64 & -.04 \\
\hline $\begin{array}{c}\text { The self-efficacy average points of } \\
\text { English writing }\end{array}$ & .81 & 1.02 \\
\hline $\begin{array}{c}\text { The self-efficacy average points of } \\
\text { English listening }\end{array}$ & .93 & .96 \\
\hline $\begin{array}{c}\text { The self-efficacy average points of } \\
\text { English speaking }\end{array}$ & .24 & .27 \\
\hline $\begin{array}{c}\text { Average points for attitude toward } \\
\text { English course }\end{array}$ & .29 & -.57 \\
\hline
\end{tabular}

The skewness values of the data set ranged from .24 to .93 while the kurtosis values ranged between-.57 and 1.02 . Can (2017) ascertained that if the skewness and kurtosis values are between +1.96 and -1.96 , this signifies an indicator of the normal distribution. Hence, the data obtained show that the data is distributed normally.

Another test conducted for assessing the normality is the Shapiro-Wilk test. Shapiro-Wilk test was recommended for normality testing when the data set consists of less than 30 participants (Can, 2017). In this study, this test was performed because the data set is 20 . The results are presented in Table 7.

Table 7. Shapiro-Wilk test results of the difference scores

\begin{tabular}{ll}
\hline & $\begin{array}{c}\text { Shapiro-Wilk } \\
(p)\end{array}$ \\
\hline The self-efficacy average points for English reading & $.47^{*}$ \\
\hline The self-efficacy average points of English writing & $.32 *$ \\
\hline The self-efficacy average points of English listening & $.09^{*}$ \\
\hline The self-efficacy average points of English speaking & $.54^{*}$ \\
\hline Average points for attitude toward English course & $.73^{*}$ \\
\hline${ }^{*} p>.05$ &
\end{tabular}


Table 8. $t$-test results on the effect of using WhatsApp on English self-efficacy and attitude toward English course

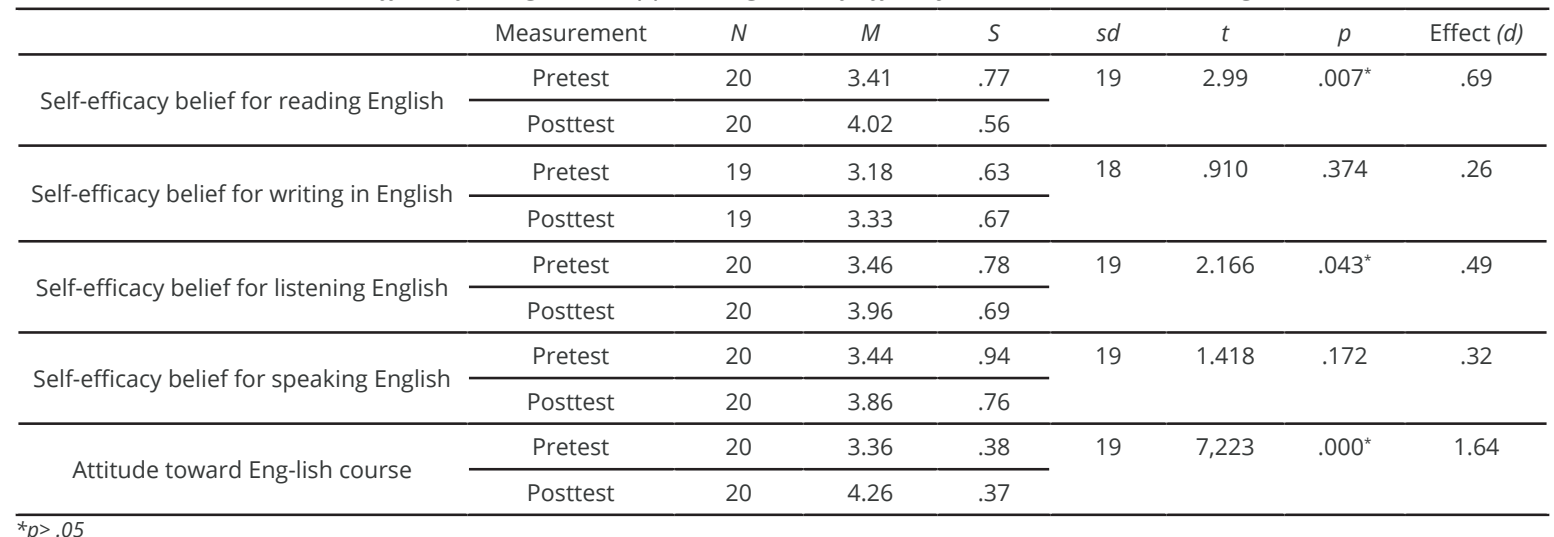

Therefore, all the values were found to be greater than 05. If the $p$ value is greater than .05 , it means that the data is normally distributed (Can, 2017).

Furthermore, the Q-Q Plot was considered to examine the normal distribution of data. At the end of Q-Q Plot, the theoretical values of the real value were overlaid and the angle was close to 45 degrees. This also reveals that the data is normally distributed.

As the normality conditions of the data sets were met, the dependent t-test was performed. The results are given in Table 8.

At the end of the research, a statistically meaningful difference was observed as the effect of WhatsApp usage on the self-efficacy beliefs of students for reading in English, $t(19)=-2.99, p<.05$. While the average of self-efficacy beliefs of the students for reading English was 3.41 before the application, it has been increased to 4.02 after the WhatsApp application. As the effect size value is .69, this exhibits a moderate effect (Taşpınar, 2017). These findings confirm that the use of WhatsApp in the group outside the school has a significant effect on self-efficacy beliefs of the students.

At the end of the research, a statistically meaningful difference was not perceived as the effect of WhatsApp usage on the self-efficacy beliefs of students for writing in English, $t(18)=-.912, p>.05$. While the average of self-efficacy beliefs of the students for writing in English was 3.18 before the application, it has been increased to 3.33 after the WhatsApp application. However, this increase is not statistically meaningful. As the effect size value is .26, this indicates a low level of impact (Taşpınar, 2017).

At the end of the research, a statistically meaningful difference was observed as the effect of WhatsApp usage on the self-efficacy beliefs of students for listening English, $t(19)=-2.166, p<.05$. While the average of self-efficacy beliefs of the students for reading English was 3.46 before the application, it has been increased to 3.96 after the WhatsApp application. This finding proves that the use of WhatsApp is significantly effective in self-efficacy beliefs of the students. As the effect size value is .49 , this exhibits a moderate effect (Taşpınar, 2017).

When the findings of the study were examined, it was seen that using WhatsApp outside of school on students' speaking skills had no statistically significant effect, $t(19)=$ $-1.418, p>.05$. The average of self-efficacy beliefs of the students for speaking in English has been increased from 3.44 to 3.86 . As the effect size value is .32, this indicates a low level of impact(Taşpınar, 2017). Although this increase is statistically meaningful, it can be assumed that there is a positive increase after the application.
At the end of the research, a statistically meaningful difference was observed in the attitudes of students toward English course after the WhatsApp application, $t(19)=$ $-7.223, p<.05$. While the average of attitudes of the students toward English was 3.36 before the application, it has been increased to 4.26 after the WhatsApp application. The effect size value of 1.64 indicates a high level of effect (Taşpınar, 2017). This finding reveals that using WhatsApp outside the school in this group has a significant effect on the attitudes of the students toward English course.

\section{Findings from Qualitative Data}

In this study, which was conducted to examine the effect of communicating in English using WhatsApp on the self-efficacy beliefs of students for English and their attitudes toward English course outside the school, the application lasted 8 weeks and after the application, a semi-structured questionnaire was applied to the students. At the end of the survey, content analysis was performed and the following themes and codes were obtained.

Table 9. Theme and codes obtained from qualitative data

Tables

\begin{tabular}{|c|c|c|}
\hline Themes & Codes & $f$ \\
\hline \multirow{2}{*}{$\begin{array}{l}\text { Self-efficacy belief } \\
\text { for listening English }\end{array}$} & Positive self-efficacy belief & 19 \\
\hline & Negative self-efficacy belief & 4 \\
\hline \multirow{2}{*}{$\begin{array}{l}\text { Self-efficacy } \\
\text { belief for speaking } \\
\text { English }\end{array}$} & Positive self-efficacy belief & 6 \\
\hline & Negative self-efficacy belief & 44 \\
\hline \multirow{2}{*}{$\begin{array}{l}\text { Self-efficacy belief } \\
\text { for reading English }\end{array}$} & Positive self-efficacy belief & 6 \\
\hline & Negative self-efficacy belief & 47 \\
\hline \multirow{2}{*}{$\begin{array}{l}\text { Self-efficacy belief } \\
\text { for writing in } \\
\text { Eng-lish }\end{array}$} & Positive self-efficacy belief & 7 \\
\hline & Negative self-efficacy belief & 33 \\
\hline \multirow{2}{*}{$\begin{array}{c}\text { Attitudes toward } \\
\text { English }\end{array}$} & Characteristics of positive attitude & 23 \\
\hline & Characteristics of negative attitude & 1 \\
\hline \multirow{6}{*}{$\begin{array}{l}\text { Emotions } \\
\text { experienced }\end{array}$} & Happiness & 16 \\
\hline & Excitement & 11 \\
\hline & Joy & 3 \\
\hline & Relief & 3 \\
\hline & Curiosity & 3 \\
\hline & Sadness & 3 \\
\hline $\begin{array}{l}\text { Problems } \\
\text { experienced during } \\
\text { the process }\end{array}$ & & 5 \\
\hline Total & & 234 \\
\hline
\end{tabular}


At the end of the study, it is observed that there are positive developments in the self-efficacy beliefs of the students about listening to English in light of the data obtained from semi-structured questionnaires. When students were questioned about their beliefs about listening, a majority of the students declared that there were positive developments in this regard. The expressions of the students mentioned below are the examples:

S3 : I think I can understand now when I listen to some thing in English.

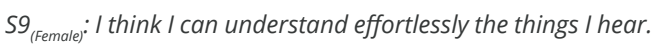

S18 ${ }_{\text {(male) }}$ Sometimes I have difficulty in understanding. But this only concerns me. I know I can understand better if I work a little more.

S12 (Female) : I understand better now in comparison to last year. Because my vocabulary has been developed and we've implemented many listening activities.

At the end of the study, few students stated that there was no positive development in self-efficacy beliefs about listening. For example;

\section{S16 $6_{\text {female: }}$ My listening skills weren't developed. They are still undeveloped. I didn't experience a change.}

$S 17_{\text {(male) }}$ : d do not trust myself about this issue.

The majority of the students stated that this study has a positive effect on the self-efficacy beliefs and their self-confidence has been increased and they feel more competent in this regard. Very few students stated that they did not experience any changes. Some opinions of the students are presented below.

S7 : When I speak, I remember the activities we have carried out and I make better sentences. I think I can do it now.

$\$ 15_{\text {male }}$ : Before, I was afraid of making mistakes, but now I can speak more freely. I'll do it. Now, I trust myself.

$S 17_{\text {(male) }}:$ I trust myself, but my speaking skill changes based on the topic.

$S 2_{\text {(Female) }}$ I believe that this practice has helped to develop my skills a little because I think about a given subject and express what I think as I wish.

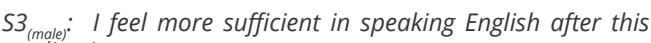
application.

S18 $8_{\text {(male) }}$ I recall the patterns and words that my friends and teacher use in WhatsApp. When I speak, I can remember these patterns and words.

S8 (Female) I did not talk too much, I was afraid to make mistakes when forming a sentence, but I have more faith in myself and I am not afraid of making mistakes. I try to express myself effortlessly.

At the end of the survey, students declared that they experienced a positive increase in self-efficacy beliefs about reading, they had more confidence in themselves in this regard. Some opinions of the students are presented below.

S17(male): I could not understand when I watched a series with English subtitles before but I feel confident that I can understand the things I read in the group or elsewhere.

$518_{\text {(Female) }}:$ I do not feel like "I cannot do it, I cannot understand" anymore. In fact, I realized that I could not achieve anything if I do not work hard.

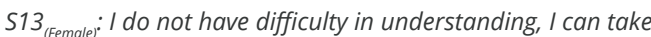
a look and understand the subject, theme, content.
S8 : I was very slow on reading. I could not advance quickly. Even I didn't want to read as I was too afraid of making mistakes. This application contributed a lot to me. We both have fun and learn.

S16 $6_{\text {Female }}:$ I didn't understand a thing when I was reading before, now at least, I can tell what is the subject about. I think I can do it.

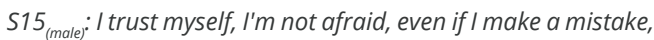
I correct it and I express it again. Only I do not understand if there are so many words that I do not know.

$S 1_{\text {(male) }}$ I trust myself and I know I can do it. I completely believe in myself.

From the qualitative data obtained, it is comprehended that very few students declared there is no change in the self-efficacy belief of the students for reading in English. The opinions of the students are given as an example.

S7 $7_{\text {male: }}$ There has not been a significant improvement in my reading skills. I am not sure.

$513_{(\text {Female) }}$ I didn't experience any change.

S17 : Fifty-fifty. Because when there are many prepositions and the conjunctions, you do not feel that confident.

When the change in the self-efficacy beliefs of students about English writing skill is examined, it is asserted that a large part of the students commonly believe that these activities increase their beliefs and that they believe they can do achieve more now. There are very few students who say they didn't experience any change in this direction. The opinions of the students are presented below.

$\mathrm{S1}_{\text {(male): }}$ I stopped thinking about a sentence many times, and I write whatever I have in mind. Then, I realized that I started to make better sentences and I was understood.

S4 $4_{\text {female: }}$ If we continue to use this study method, I think that I can easily reach the writing level that I want to have in both social media and in class.

S9 ${ }_{\text {(female) }}$ I'm feeling better and I believe I will be much better.

$513_{(f e m a l e)}$ I think I am more skilled in writing than the other areas. I have the right to correct, change or develop my opinion at any time. And I can write. I believe in myself. I also learn new ideas and conjunctions by talking about the application and this contributes more to my writing.

S3 $3_{\text {female) }}:$ A positive change occurred to me when we started to use this application, I feel like I can write something new from scratch.

S5 : After the application, I observed the sentences of other people and compared them with my own sentences, and I discovered my mistakes. Hence, I started to build stronger sentences.

S14 female): I learned where and how to use the prepositions and the conjunctions and literally my self-confidence has been increased.

Within the scope of the research, students were asked questions about their attitudes toward English and in the end, it has been revealed that a large part of the students developed positive attitudes. Some opinions of the students are presented below.

S1 : After this application, I realized that English is not something to be afraid of, that I can easily speak and communicate with other persons using English. For me, the lessons used to be boring in the past, and now I am looking forward to the English lesson.

S2 (female): Truly, I think about the topic given in the group even I am not very involved in the discussion, and I realized that I can make the sentences instantly. 
S3 ${ }_{\text {(male) }}:$ I think that it is not difficult to use English in our daily lives and that it is delightful to achieve this. At the end of the application, my motivation for the English course considerably increased.

S4 $4_{(f e m a l e)}$ I I started to like it more. I started to like English more.

S5 $5_{\text {(female) }}$ Although I used to like English in the past, I could not completely concentrate on the course, but right now, my judgment has been changed and it is more efficient now.

$S 7_{\text {(male) }}$ : Since it was not an application we are accustomed to, it was interesting for was and I feel more committed to the English course for the time being.

At the end of the research, it has been ascertained that the students developed positive emotions and experienced emotions such as excitement, pride, happiness, curiosity, and relief. The opinions of the students about the emotions experienced by the students are presented below.

S7 $7_{\text {mate: }}$ When I translate something, as I write about a topic or when I read something, I am happy to feel that I have ac complished something.

$510_{(f e m a l e)}$ I feel excited since I learnt new things.

$S 11_{\text {(male }}$ : I feel comfortable and I'm learning English by having fun, I do not get bored.

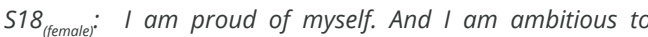
achieve more.

$S 2_{\text {(female) }}$ I feel that I am advancing day by day and I am both curious and enjoying myself.

S5 $5_{\text {female: }}$ Suddenly, I am getting involved in the subject. I can comment, write about it and I can understand. This motivates me and makes me happy at the same time.

Within the scope of the research, students were invited to express the problems they have experienced during this application. In this context, students mentioned that sometimes they had connection problems, they could not keep up with the speed of the conversation on WhatsApp, sometimes they didn't have access to the Internet and sometimes they got bored because of the topics that have been discussed. The opinions of the students about this situation are presented below.

S19(male): There was an activity I could not join since I didn't have access to the Internet. This is frustrating.

S15(male): I am not very active in the conversation and sometimes the topics are boring. Some of my friends do not have a cell phone or they do not have time.

S8(female): I am too slow to follow the conversation. I can't write so fast and get things together.

S10(female): Sometimes there are problems and the screen freezes.

\section{Discussion}

This study examines the effect of "WhatsApp" usage on the attitudes of students toward English self-efficacy and English course in English language education outside the school. Hence, an application that lasts 8 weeks was implemented and the quantitative and qualitative processes were used to examine the effects of this application. At the end of the research, a statistically meaningful difference was observed as the effect of WhatsApp usage on the self-efficacy beliefs of students for reading in English. The data obtained from the separate qualitative process prove this argument as well. At the end of the survey, students declared that they experienced a positive increase in self-efficacy beliefs about reading, they had more confidence in themselves, in this regard, when they are reading a text in English. When we review the literature, it was comprehended that using WhatsApp has a positive effect on the reading of English (Plana, Gimeno, Appel, \& Hopkins, 2013). Also in the literature, it was apprehended that using WhatsApp encouraged students to read and it helped the students to believe in themselves (Plana, Gimeno, Appel, \& Hopkins, 2013; Alshammari, Parkes, \& Adlington, 2017). The findings obtained correspond to the studies mentioned in the literature.

At the end of the research, it was noted that a statistically meaningful difference wasn't perceived as the effect of WhatsApp usage on the self-efficacy beliefs of students for writing in English However, although there was no meaningful difference according to the results of the study, it was witnessed that there was an increase in the average scores on the pretest and posttest results. Furthermore, information obtained from qualitative processes confirms this finding. According to the semi-structured questionnaire, the students stated that they could now express their feelings and thoughts by making sentences, they feel better, their confidence to write any text has been increased and they also believe that they could write more easily. When we examine the literature, Fattah (2015) declared that the WhatsApp application has a positive effect on the writing skills of the students. Considering the significance of vocabulary knowledge in order to communicate effectively in the target language, it is apprehended from the literature that the use of WhatsApp has a positive effect in this regard as well (Alsaleem, 2013; Jafari \& Chalak, 2016). In the literature review, no studies have been observed on the self-efficacy belief in writing.

The results of the research reveal that using WhatsApp in English outside the course has a statistically meaningful effect on self-efficacy beliefs of the students. The data obtained from qualitative means also confirm this as well. The students asserted that they thought they could understand any text they are listening to at the end of the study and that they experienced an improvement in their skills compared to the previous years and that they feel more confident about it. When the literature is analyzed, no study has been discovered on the self-efficacy belief for listening in English.

At the end of the research, it was remarked that a statistically meaningful difference wasn't perceived as the effect of WhatsApp usage on the self-efficacy beliefs of students for writing in English. However, there is an apparent increase in the averages of pretest and posttest. According to the results obtained from the qualitative data, it was witnessed that the practice created a positive effect on the speaking skills of the students. Indeed, the majority of the students stated that this study has a positive effect on the self-efficacy beliefs and their self-confidence has been increased and they feel more competent in this regard. Manan (2017) asserted that the use of WhatsApp for foreign language education is effective since it allows the students to develop the communication skills in the target language, also, their speaking skills are being developed in the meantime. In the literature review, no studies have been found on the self-efficacy belief in speaking.

At the end of the study, the attitudes of the students toward English were analyzed and it was understood that using WhatsApp in English had a meaningful effect on attitude toward English. The data obtained from qualitative means also prove this as well. The students stated that they are no longer afraid of English, they feel confident in themselves, they are more willing to learn and they start to enjoy the lesson even more. In the literature review also, the use of WhatsApp was determined to be effective in developing positive attitudes of students toward the 
courses (Manan, 2017). In the study conducted by Şahan, Çoban and Razı (2016) about teaching English idioms through WhatsApp, they have mentioned that the use of WhatsApp was influential in foreign language teaching and there were some positive changes in attitudes and motivations of the students. Likewise, Fattah (2015) has proved that this application has positive effects on students, allows students to express themselves more comfortably, and develop positive thoughts about the language.

At the end of the research, the emotions of the students about WhatsApp were considered in the qualitative process and it was ascertained that students usually experienced positive emotions such as happiness, excitement, pride, curiosity, and relief. When the literature about the effects of WhatsApp usage on the emotions experienced by the students is reviewed, similar results have been collected and it has been remarked that the students feel more comfortable and have the opportunity to learn in a comfortable environment (Fattah, 2015; Manan, 2017). Pekrun, Goetz and Perry (2002) declared that emotions have an important impact on both the learning process and the learning outcomes. Control-value theory asserts that positive or negative feelings experienced in learning environments are indicators for predicting the academic achievements of the students (Pekrun, 2006). In this study, it is apprehended that the positive emotions experienced are an indicator for the students even though the academic success of the students is not taken into consideration.

At the result of the research, it is noted that some problems are encountered during the study from the data obtained from the qualitative processes. In general, the problems can be listed as follows; technical problems, the fact that the students do not find the topic interesting, the fact that the student cannot keep up with the speed of the friends in the group.

\section{Conclusions and Recommendations}

The purpose of this study is to investigate the effects of the use of WhatsApp in English on English self-efficacy beliefs and attitudes and thus to contribute to the literature on the use of social media in English education. In this context, the following results are obtained:

- The use of WhatsApp in English outside the school has a positive effect on reading, writing, speaking and listening self-efficacy beliefs of the students.

- Furthermore, the use of WhatsApp in English outside the school has a positive effect on attitudes of the students toward English course.

- Students experienced positive emotions such as happiness, joy, pride, relief, and excitement during the application.

- It was mentioned that the opinions of the students about the use of the practice were positive and they supported the use of this application for learning English.

Thus, the following recommendations can be presented according to the data obtained at the end of the study:

-WhatsApp in English outside the school can be used to improve positive attitudes of the students toward the English course.

- WhatsApp in English outside the school can be used to improve self-efficacy belief of the students in English.
- The research was conducted for the English course and the effectiveness of the system in several courses may be examined in prospective studies.

- WhatsApp is used as a social media tool in this research. In future research, diverse social media tools can be used and the results of the researches can be compared

\section{References}

Akkaş, F., \& Coker, B. (2016). The use of communicative approach in 9th grade EFL class. Eurassian Journal of Educational Research, 71-90.

Alport, G. W. (1954). The nature of prejudice. London: Addison-Wesley.

Alsaleem, B. I. (2013). The Effect of "WhatsApp" Electronic Dialogue Journaling on Improving Writing Vocabulary Word Choice and Voice of EFL Undergraduate Saudi Students. Arab World English Journal, 4(3), 213-225.

Alshammari, R., Parkes, M., \& Adlington, R. (2017). Using WhatsApp in EFL Instruction with Saudi Arabian University Students. Arab World English Journal, 6884.

Aydın, S., \& Zengin, B. (2008). Yabancı dil öğreniminde kaygl: Bir literatür özeti. Journal of Language and Linguistic Studies, 4(1), 81-94.

Bandura, A. (1977). Self-efficacy: Toward a unifying theory of behavioural change. Psychological Review, 84(2), 191-215.

Baran, G., \& Halıcı, P. (2006). Çocuklarda yabancı dil eğitimi. Eurasian Journal of Educational Research, 24, 44-52.

Bardakcı, S., \& Keser, H. (2017). Bilişim Teknolojilerinin eğitime entegrasyonu. Ankara: Nobel Yayıncılık.

Bartram, B. (2010). Attitudes to modern foreign language learning. London: Continuum.

Can, A. (2017). SPSS ile bilimsel araştırma sürecinde nicel veri analizi. Ankara: Pegem.

Cuban, L. (1994). Computers met classrooms: Who wins? Education Digest, 50-54.

Çelebi, M. D. (2006). Türkiye'de Anadili Eğitimi ve YabanCı Dil Öğretimi. Sosyal Bilimler Enstitüsü Dergisi 21, 285-307.

Demirpolat, B. C. (2015). Türkiye'nin yabancı dil öğretimi ile imtihanı, sorunlar ve çözüm önerileri. Siyaset, Ekonomi ve Toplum Araştırmaları Vakfı, 1-24.

EF EPI. (2018, 09 28). https://www.ef.com.tr/epi/ adresinden alındı

Fattah, S. F. (2015). The Effectiveness of Using WhatsApp Messenger as One of Mobile Learning Techniques to Develop Students' Writing Skills. Mobile Learning Techniques to Develop Students' Writing Skills, 115127.

Gardner, R. C. (1985). Social psychology and second language learning. London: Edward Arnold.

Gedikoğlu, T. (2005). Avrupa Birliği Sürecinde Türk Eğitim Sistemi. Mersin Üniversitesi Eğitim Fakültesi Dergisi, 1(1), 66-80. 
Gökdemir, C. V. (2010). Üniversitelerimizde verilern yaban$\mathrm{Cl}$ dil öğretimindeki başarı durumumuz. Erzurum Üniversitesi Sosyal Bilimler Enstitüsü Dergisi, 8, 251264.

Gökmen, Ö. F., Duman, I.., \& Horzum, M. B. (2016). Uzaktan eğitimde kuramlar, değişimler ve yeni yönelimler. Açıköğretim Uygulamaları ve Araştırmaları Dergisi, 2(3), 29-51.

Jafari, S., \& Chalak, A. (2016). The Role of WhatsApp in Teaching Vocabulary to Iranian EFL Learners at Junior High School. English Language Teaching, 9(8), 85-92.

Karasar, N. (2014). Bilimel Araştırma Yöntemleri. Ankara: Nobel Akademi Yayıncılık.

Kazazoğlu, S. (2013). Türkçe ve İngilizce Derslerine Yönelik Tutumun Akademik Başarıya Etkisi. Eğitim ve Bililm, 38(170), 294-307.

Kemp, S. (2018, 10 11). We are social. Global Digital Report 2018: Retrived from https://wearesocial.com/ blog/2018/04/social-media-use-jumps-in-q1-despite-privacy-fears

Levin, T., Naama, S., \& Zipora, L. (1991). Achievements and attitudinal patterns of boys and girls in science. Journal of Research in Science Teaching, 28(4), 315328.

Manan, N. A. (2017). WhatsApp Mobile Tool In Second Language Learning. Indonesan EFL Journal, 3(1), 87-92.

Ocak, G., \& Karakuş, G. (2014). Öğrencilerin hazırbulunuşluk düzeyleri ve İngilizce dersine yönelik tutumları arasındaki ilişkinin incelenmesi. Ekev Akademi Dergisi, 58, 681-698.

Orakcı, Ş. (2017). Öğrenen özerkliğine dayanan öğretim etkinliklerinin 6. sınıf öğrencilerinin ingilizce başarılarına tutumlarına, öğrenen özerkliklerine ve kalıcı öğrenmelerine etkisi (Unpublished Doctoral Thesis). Gazi Üniversitesi, Eğitim Bilimleri Enstitüsü, Ankara.

Pekrun, R. (2006). The Control-Value Theory of achievement emotions: Assumptions, corollaries, and Implications for educational research and practice. Educational Psychology Review, 18, 315-341.

Pekrun, R., Goetz, T., \& Perry, R. (2002). Academic emotions in students' selfregulated learning and achievement: A program of quantitative and qualitative research. Educational Psychologist, 37, 91-106.

Plana, M. G., Gimeno, A., Appel, C., \& Hopkins, J. (2013). Global perspectives on Computer-Assisted Language Learning. Improving learners' reading skills through instant short messages: a sample study using WhatsApp (pp. 80-84). Glasgow: WorldCALL.

Roblyer, M., \& Wiencke, W. (2003). Design and use of a rubric to assess and encourage interactive qualities in distance courses. American Journal of Distance Education, 17(2), 77-98.

Salmon, G. (2002). E-tivities: The key to active online learning. London: Kogan Page.

Siemens, G. (2006). Connectivism: Learning Theory or Pastime for the Self-Amused? elearnspace.

Siemens, G., \& Tittenberger, P. (2018, 10 12). Handbook of Emerging Technologies for Learning. Retrived form http://elearnspace.org/Articles/HETL.pdf
Şahan, Ö., Çoban, M., \& Razı, S. (2016). İngilizce deyimlerin WhatsApp aracılığıyla öğretimi: Akıllı telefonların sınıf dışı kullanımı. Erzincan Üniversitesi Eğitim Fakültesi Dergisi, 18(2), 1230-1251.

Taşpınar, M. (2017). Sosyal Bilimlerde SPSS Uygulamalı Nicel Veri Analizi. Ankara: Pegem Akademi yayıncılık. doi:10.14527/9786052410585

TEPAV. (2014). Türkiyede'ki Devlet Okullarında Ingilizce Dilinin Öğretimine Iliş̧kin Ihtiyaç Analizi. Ankara: British Council.

Yanar, B. H. (2008). Yabancı Dil Hazırlık Eğitimi Alan ve Almayan Anadolu Lisesi Öğrencilerinin Yabancı Dil Öz Yeterlik Algılarının ve Ingilizce Dersine Yönelik TutumIarının iincelenmesi (Unpublished Master Thesis). Ege Üniversitesi Sosyal Bilimler Enstitüsü. İzmir.

Yanar, B. H., \& Bümen, N. (2012). İngilizce ile ilgili özyeterlik inancı ölçeğinin geliştirilmesi. Kastamonu Eğitim Dergisi, 20(1), 97-110.

Yıldııım, A., \& Şimşek, H. (2013). Sosyal Bilimlerde Nitel Araştırma Yöntemleri. Ankara: Seçkin.

Yılmaz, E., Yiğit, R., \& Kaşarcı, İ. (2012). İlköğretim öğrencilerinin özyeterlilik düzeylerinin akademik başarı ve bazı değişkenler açısından incelenmesi. Mehmet Akif Üniversitesi Eğitim Fakültesi Dergisi, 23, 371-388.

Zimmerman, B. J. (2000). Self-efficacy: An essential motive to learn. Contemporary Educational Psychology, 25, 82-91. 